\title{
Pemanfaatan Youtube dan Edpuzzle sebagai Media Pembelajaran Daring Berbasis Video Interaktif
}

\author{
Nanda Lailatul Qadriani ${ }^{*}$, Sri Hartati ${ }^{1}$, Anitasa Dewi ${ }^{1}$ \\ ${ }^{1}$ Program Studi Bahasa Mandarin dan Kebudayaan Tiongkok, Fakultas Ilmu Pengetahuan Budaya, \\ Universitas Al Azhar Indonesia, Jl. Sisingamangaraja, Kompleks Masjid Agung Al Azhar, Kebayoran \\ Baru, Jakarta Selatan, 12110 \\ Email Penulis Korespodensi: nanda.lailatul@uai.ac.id
}

\begin{abstract}
Pandemic Covid-19 which led to the transformation of offline to online learning requires educators to innovate in learning. Various applications and online media are becoming increasingly popular to be used as learning supports, including Youtube and Edpuzzle which can be used as learning support platforms with interactive, effective and fun videos for students. This community service activity aims to socialize the use of Youtube and Edpuzzle which can be a reference for learning media in online classes. The participants are teachers from High School in Sudin I and II of Central Jakarta area and Chinese teachers association in Jabodetabek. The implementation of this service uses the lecture method for delivering material and direct practice of designing learning videos with Edpuzzle. The result of this community service activity is that teachers can make Edpuzzle learning videos, they feel this training is very useful and will apply it in learning in the subjects they teached
\end{abstract}

Keywords: Youtube, Edpuzzle, Online learning media, Interactive video

\begin{abstract}
Abstrak
Pandemi Covid-19 yang menyebabkan transformasi pembelajaran luring menjadi daring menuntut pendidik untuk melakukan inovasi dalam pembelajaran. Berbagai aplikasi dan media online menjadi semakin populer untuk dijadikan media pembelajaran, diantaranya adalah Youtube dan Edpuzzle yang dapat dijadikan platform penunjang pembelajaran dengan media video yang interaktif, efektif dan menyenangkan bagi siswa. Kegiatan abdimas ini bertujuan untuk mensosialisasikan penggunaan Youtube dan Edpuzzle agar dapat menjadi referensi media pembelajaran di kelas daring. Peserta kegiatan adalah guru-guru SMA/Sederajat Wilayah Sudin I dan II Jakarta Pusat dan guru-guru MGMP Bahasa Mandarin di Jabodetabek. Pelaksanaan abdimas ini menggunakan metode ceramah untuk penyampaian materi dan praktik langsung perancangan video pembelajaran dengan Edpuzzle. Hasil dari kegiatan abdimas ini adalah guru-guru dapat membuat video pembelajaran Edpuzzle, mereka merasa pelatihan ini sangat bermanfaat dan akan menerapkannya dalam pembelajaran mata pelajaran yang mereka ampu..
\end{abstract}

Kata kunci: Youtube, Edpuzzle, Media pembelajaran daring, Video interaktif

\section{PENDAhuluan}

Pandemi Covid-19 yang menyebar sejak awal tahun 2020 ke seluruh dunia mengubah tatanan kehidupan manusia di segala bidang serta menuntut manusia untuk mampu beradaptasi dengan kondisi normal baru. Di dalam bidang pendidikan, perubahan model pembelajaran dari luring menjadi daring menyebabkan pendidik harus menyesuaikan strategi dan metode pembelajaran.

Pada awal penerapan pembelajaran daring di Indonesia, terdapat banyak sekali kendala yang ditemukan baik oleh pendidik maupun peserta 
didik di tingkat sekolah dasar, menengah hingga perguruan tinggi. Berbagai sosialisasi untuk menunjang pembelajaran daring terus diadakan. Sosialisasi dan webinar ini di satu sisi sangat membantu para tenaga pengajar dalam menemukan strategi, metode dan media pembelajaran yang dapat diterapkan pada kelas daring yang mereka ampu. Namun di sisi lain, banyaknya strategi, metode dan media pembelajaran yang diperkenalkan cukup membuat para pengajar kebingungan memilih strategi, metode dan media mana yang paling sesuai digunakan. Hal ini dikarenakan pada kebanyakan webinar hanya menyebutkan strategi, metode atau media apa saja yang dapat dimanfaatkan dalam pembelajaran daring, tanpa memaparkan bagaimana penggunaan, kelebihan dan kekurangan serta tingkat keefektivitasannya.

Menurut Iskandarwassid dan Sunendar, (2011: 9), strategi pembelajaran meliputi kegiatan atau pemakaian teknik yang dilakukan oleh pengajar mulai dari perencanaan, pelaksanaan kegiatan sampai ke tahap evaluasi, serta program tindak lanjut yang berlangsung dalam situasi edukatif untuk mencapai tujuan tertentu, yaitu pengajaran. Menurut Sanjaya (2010 : 186), strategi pembelajaran merupakan rencana tindakan (rangkaian kegiatan) termasuk penggunaan metode dan pemanfaatan berbagai sumber daya/kekuatan dalam pembelajaran.

Dalam pembelajaran bahasa khususnya bahasa Mandarin secara daring, terdapat tiga metode pembelajaran yang dapat diterapkan. Metode pembelajaran tersebut meliputi pembelajaran tatap maya (sinkronus), pembelajaran mandiri dan pembelajaran dengan media audio-visual (asinkronus) (苏娟, 2020). Ketiga metode ini sebaiknya diterapkan secara bergantian karena memiliki keunggulan dan kekurangan masing-masing. Selain itu, penerapan metode yang variatif dalam pembelajaran juga dapat meningkatkan motivasi dan mengurangi kebosanan siswa dalam belajar.

Metode pembelajaran tatap maya memungkinkan adanya interaksi langsung antara pendidik dan peserta didik. Guru juga dapat mengontrol kondisi siswa saat proses pembelajaran berlangsung. Jika ada pertanyaan, siswa dapat bertanya langsung kepada guru. Metode pembelajaran tatap maya tidak berbeda jauh dengan pembelajaran tatap muka di kelas, hanya saja dalam pembelajaran tatap maya, dan webinar tentang strategi, metode dan media (aplikasi dan website) yang dapat digunakan guru dan siswa bertemu di dalam ruang kelas virtual. Kekurangan metode ini adalah diperlukan jaringan internet yang stabil dan kuota yang besar, sehingga pada beberapa peserta didik yang tidak memiliki jaringan internet yang baik seringkali mengalami kendala berupa jaringan terputus atau penggunaan kuota data internet yang boros. Selain itu, kondisi tempat belajar peserta didik yang kurang kondusif sangat memengaruhi konsentrasi mereka saat belajar. Adapun platform atau media yang biasa digunakan dalam pembelajaran tatap maya adalah Zoom, Ms. Team, Skype, Google Meet dan lain-lain.

Pada metode pembelajaran mandiri, peserta didik dituntut untuk mengeksplorasi tema ataupun materi yang diberikan oleh pendidik sesuai dengan tingkat pemahaman dan ketertarikan mereka. Pembelajaran mandiri diterapkan untuk meningkatkan kemandirian belajar peserta didik agar terbiasa untuk berpikir kritis, kreatif dan inovatif. Dalam penerapan metode pembelajaran mandiri, sangat dibutuhkan rasa tanggungjawab yang besar dari peserta didik untuk mengeksplor materi dan menyelesaikan tugas-tugas yang diberikan sesuai dengan instruksi pendidik. Jika tidak, maka peserta didik tidak mendapatkan ilmu yang maksimal, sehingga target pembelajaran pun sulit tercapai.

Selanjutnya adalah metode pembelajaran berbasis media audio-visual atau disebut juga pembelajaran dengan video. Metode pembelajaran dengan video bukan merupakan metode yang asing dalam dunia pembelajaran. Menurut Dwyer, media audio visual yang masuk melalui panca indera mata dan telinga dapat menarik perhatian manusia sebesar $94 \%$. Manusia umumnya juga dapat mengingat paling tidak $50 \%$ dari apa yang dilihat dan didengarnya (Oktaviani, 2020). Pemanfaatan video dalam pembelajaran menjadi semakin populer sejak diterapkannya pembelajaran daring. Platform untuk melihat video seperti Youtube, Youku, iQiyi dan sebagainya menjadi semakin ramai dengan video-video pembelajaran. Pendidik dapat memanfaatkan video-video pembelajaran yang ada di internet, namun bisa juga membuat sendiri video pembelajaran sesuai dengan materi yang akan disampaikan ke peserta didik.

Kelebihan dari pembelajaran dengan video adalah peserta didik memiliki waktu yang lebih 
fleksibel dalam belajar, video mudah diakses dan dapat diulang-ulang jika ada bagian yang pembelajaran tatap maya. Youtube sebagai salah satu platform yang menyediakan milyaran video dengan berbagai tema dapat menjadi sumber belajar yang sangat luas bagi peserta didik. Video-video di Youtube sebagian besar bersifat open access, dapat diakses oleh siapapun dan gratis. Oleh karena itu, pendidik dapat dengan leluasa menyeleksi dan memanfaatkan video yang ada di Youtube untuk dijadikan bahan penunjang pembelajaran di kelas. Pendidik juga dapat mengunggah video pembelajaran yang dibuat sendiri untuk dimanfaatkan peserta didiknya maupun orang lain yang memerlukan ilmu tersebut.

Namun, pembelajaran dengan video baik yang diunggah di platform Youtube atau aplikasi berbagi data/video lainnya juga memiliki kekurangan, salah satunya adalah pendidik kesulitan untuk mengontrol apakah video yang dibagikan ke peserta didik ditonton secara utuh ataukah ada bagian yang dilewati (skip). Jika ada bagian yang dilewati, tentunya akan mengurangi keefektifan pembelajaran dengan video karena ada bagian materi yang tidak dipelajari oleh peserta didik.

Agar pembelajaran dengan video dapat terkontrol dengan baik oleh pendidik, maka diperlukan suatu platform atau media yang memiliki fitur mencegah video dilewati (prevent skipping) dan menganalisis bagaimana pembelajaran dengan video yang dilakukan peserta didik. Salah satu platform yang memiliki fitur tersebut adalah Edpuzzle.
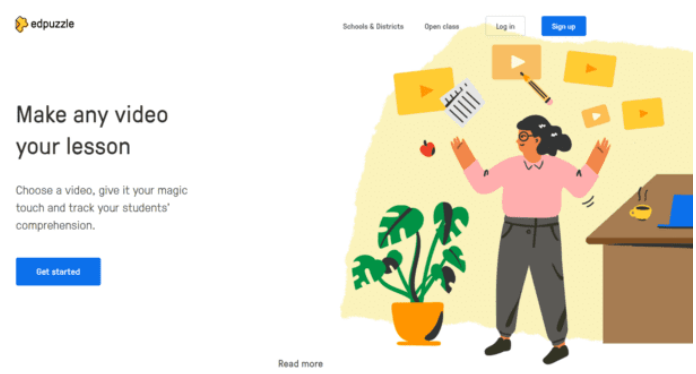

Gambar 1. Halaman utama situs Edpuzzle

Edpuzzle adalah sebuah platform
pembelajaran audio-visual yang
memungkinkan pendidik untuk mengedit video,
memotong dan merekam suara serta
menambahkan pertanyaan-pertanyaan di dalam
video (Website Edpuzzle, 2021). Edpuzzle
membuat kegiatan menonton video
pembelajaran menjadi lebih interaktif dan

tidak dipahami. Menonton video juga tidak memerlukan kuota yang besar seperti pada menyenangkan (Kompas, 2020). Siswa harus fokus dalam menonton video agar dapat menjawab pertanyaan-pertanyaan yang muncul. Beberapa kelebihan fitur yang dimiliki platform Edpuzzle adalah sebagai berikut :

- Peserta didik tidak dapat melewati (skip) isi video. Video juga akan otomatis berhenti jika siswa beralih tab atau jendela. Hal ini dapat menjaga fokus peserta didik saat menonton video pembelajaran.

- Video dalam Edpuzzle dapat diambil dari video Youtube, National Geographic, Khan Academy dan beberapa situs lainnya dengan cara memasukkan tautan video di kolom pencarian konten Edpuzzle. Video juga dapat diunggah dari perangkat laptop atau ponsel pendidik sendiri.

- Pertanyaan yang dapat dimasukkan di tengah video Edpuzzle tidak dibatasi. Pendidik juga dapat mengatur jenis soal yang muncul di pertengahan video. Edpuzzle menyediakan bentuk soal pilihan ganda dan essay, serta catatan yang dapat ditambahkan di dalam video.

- Pendidik juga dapat mengetahui durasi menonton video serta statistik penyelesaian soal-soal yang dikerjakan peserta didik, misalnya pada video bagian tertentu berapa kali peserta didik melakukan pemutaran ulang, di soal mana peserta didik menjawab benar atau salah dan sebagainya.

- Pendidik dapat memberikan umpan balik (feedback) terhadap jawaban peserta didik baik secara otomatis maupun manual.

- Pada bentuk soal pilihan ganda, penilaian dapat dilakukan secara otomatis oleh sistem Edpuzzle, sehingga peserta didik dapat langsung melihat perolehan nilai mereka setelah selesai menonton video pembelajaran.

Penerapan metode pembelajaran video dengan Edpuzzle ini telah penulis terapkan dalam pembelajaran mata kuliah Kemahiran Bahasa Lisan dan Tertulis di Program Studi Bahasa Mandarin dan Kebudayaan Tiongkok UAI. Hasil kuesioner yang kami bagikan kepada mahasiswa di akhir semester ganjil 2020/2021 menunjukkan sebanyak 54,8\% mahasiswa menyukai pembelajaran video dengan Edpuzzle, sementara 27,3\% menyukai pembelajaran tatap maya, dan masing-masing 9,1\% menyukai pembelajaran mandiri dan 
pembelajaran video di Youtube dan penugasan di sistem E-learning UAI. Mahasiswa merasa menonton dan mengerjakan tugas di Edpuzzle sangat menarik seperti sedang belajar sambil bermain game kuis, mereka menjadi lebih fokus dan tidak mudah bosan dalam menonton video karena merasa penasaran dengan soalsoal yang akan muncul di pertengahan video. Selain menarik, para mahasiswa merasa pembelajaran dengan Edpuzzle juga sangat efektif, dimana tingkat pemahaman terhadap materi dan latihan yang diberikan mencapai $81 \%$.

Berdasarkan pengalaman serta hasil penelitian tindakan kelas yang telah kami lakukan, dapat diketahui bahwa Edpuzzle merupakan salah satu platform yang dapat dimanfaatkan untuk pembelajaran daring berbasis video yang menarik, interaktif dan juga efektif.

Oleh karena itu, dalam kegiatan pengabdian masyarakat Sharing for Indonesia (S4I) periode ke-14 yang diinisiasi oleh Lembaga Penelitian dan Pengabdian Masyarakat (LP2M) UAI, kami mengangkat tema "Sosialisasi Metode Pembelajaran Bahasa Mandarin Daring dengan Youtube dan Edpuzzle bagi Guru SMA/Sederajat Wilayah Jabodetabek" untuk membagikan ilmu dan pengalaman terkait metode pembelajaran luring dan daring yang ada di UAI secara umum, serta pembelajaran dengan media video Edpuzzle pada khususnya. Sosialisasi dan pelatihan yang diadakan secara daring ini bertujuan untuk menambah referensi metode pengajaran bagi guru dengan memanfaatkan platform Youtube dan Edpuzzle sebagai media pembelajaran berbasis video yang interaktif dan efektif untuk diterapkan di kelas.

\section{METODE}

\section{Waktu dan Tempat Pelaksanaan}

Kegiatan sosialisasi dan pelatihan ini diselenggarakan pada tanggal 25 Juni 2021 pukul 14.00-16.00 WIB secara daring dengan menggunakan media Zoom.

\footnotetext{
Alat dan Bahan:

Peserta kegiatan adalah 18 orang guru bahasa Mandarin SMA/Sederajat yang ada di wilayah Sudin 1 dan 2 Jakarta Pusat serta guru-guru yang tergabung di dalam Musyawarah Guru
}

Mata Pelajaran (MGMP) Bahasa Mandarin Jakarta. Baik panitia yang terdiri dari dosen dan mahasiswa maupun peserta diminta untuk menggunakan laptop selama kegiatan berlangsung. Selain itu, narasumber yang merupakan dosen tetap prodi juga mempersiapkan materi yang ditampilkan dalam bentuk powerpoint.

\section{Langkah Pelaksanaan}

Metode yang digunakan dalam pelaksanaan kegiatan abdimas ini adalah metode ceramah dan praktik langsung. Adapun tahapan persiapan hingga pelaksanaan kegiatan adalah sebagai berikut.

1. Tahapan persiapan

Beberapa bulan sebelum kegiatan abdimas ini diselenggarakan, melalui grup whatsapp S4I, kami bertanya kepada guru-guru mata pelajaran bahasa Mandarin tentang tema pelatihan apa yang mereka butuhkan untuk menunjang kompetensi diri dan pengajaran bahasa Mandarin di kelas. Guru bahasa Mandarin berharap diadakannya pelatihan tentang aplikasi pembelajaran dalam bentuk kuis atau games untuk meningkatkan motivasi siswa dalam belajar. Kami meminta guru-guru tersebut untuk menuliskan aplikasi atau media apa saja yang pernah mereka gunakan, namun tidak satupun yang menyebutkan pernah menggunakan media Edpuzzle.

Dalam pembelajaran di kelas, kami sudah menggunakan media Youtube dan Edpuzzle sebagai salah satu metode pembelajaran interaktif. Riset tindakan kelas yang kami lakukan juga menunjukkan mahasiswa merasa pembelajaran dengan Youtube yang disambungkan dengan Edpuzzle sangat menyenangkan, mereka seperti sedang belajar sambil bermain games. Oleh karena itu, kami memutuskan untuk mengambil tema pelatihan pembelajaran berbasis video dari Youtube dan Edpuzzle dalam kegiatan pengabdian masyarakat ini.

2. Tahapan penyusunan materi

Materi dalam kegiatan pengabdian masyarakat ini terbagi menjadi dua judul. Pertama adalah tentang metode pembelajaran secara umum dan metode yang diterapkan dalam pembelajaran bahasa Mandarin di UAI. Materi kedua tentang metode pembelajaran daring, teknik 
membuat video pembelajaran, dan penjelasan tentang fitur-fitur di situs Edpuzzle beserta kekurangan dan kelebihannya.

\section{Tahapan pelaksanaan}

Pelaksanaan kegiatan pengabdian masyarakat ini terdiri dari 5 sesi. Sesi pertama adalah penyampaian materi oleh dosen narasumber. Sesi kedua adalah simulasi penggunaan Edpuzzle, dimana para peserta diminta menonton video dan mengerjakan tugas yang sudah dipersiapkan oleh panitia melalui situs Edpuzzle. Sesi ketiga panitia memberikan petunjuk tahapan bagaimana merancang sebuah video pembelajaran dengan Edpuzzle, peserta juga diminta mempraktikkan tahapan dan membuat sebuah video penugasan di Edpuzzle. Dalam praktik ini, panitia sudah menyiapkan 4 video pendek tentang pembelajaran bahasa Mandarin tingkat dasar dari kanal Youtube untuk disambungkan ke situs Edpuzzle. Sesi keempat, peserta diminta untuk mempresentasikan hasil rancangan videonya. Sesi kelima adalah tanya jawab antara panitia dan peserta terkait pelatihan pemanfaatan media Youtube dan Edpuzzle serta bertukar informasi dan pengalaman terkait pembelajaran daring yang diterapkan.

\section{HASIL DAN PEMBAHASAN}

Dalam pemaparan materi tentang metode pembelajaran bahasa Mandarin di UAI dan metode pembelajaran bahasa Mandarin secara daring, para guru terlihat sangat antusias. Materi yang disampaikan berdasarkan pengalaman dan riset para dosen narasumber dalam praktik pembelajaran bahasa Mandarin di kelas, sehingga metode pembelajaran yang dipaparkan adalah metode yang sudah diterapkan dan terukur hasilnya. Ini dapat menjadi referensi bagi guru-guru dalam pengembangan metode pembelajaran di kelas.
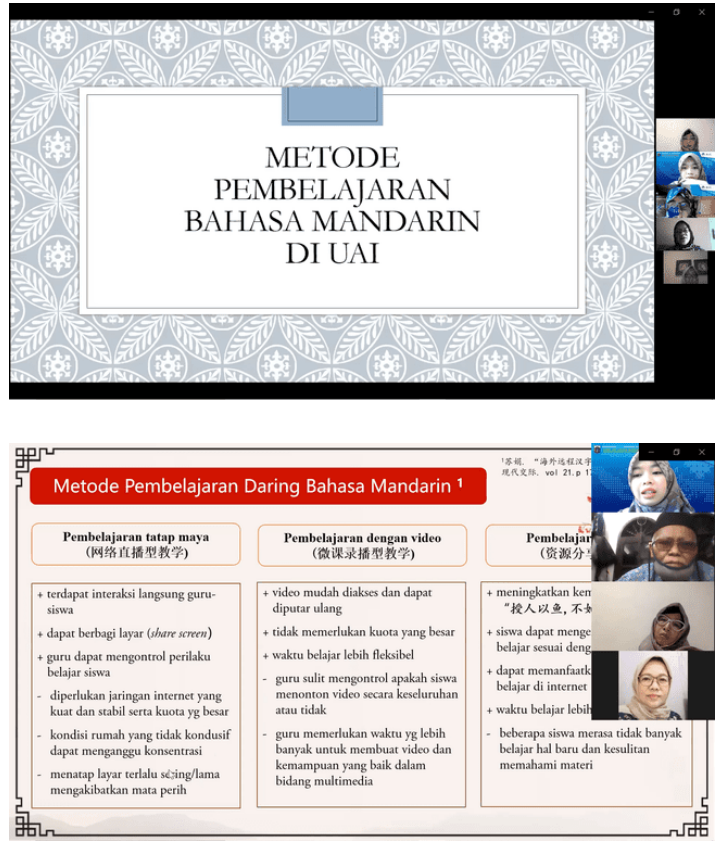

Gambar 2. Pemaparan Materi I (atas) dan Materi II (bawah)

Dalam sesi simulasi penggunaan Edpuzzle, sebanyak 14 orang guru bergabung di kelas simulasi yang sudah disiapkan oleh panitia. Beberapa guru tidak dapat bergabung dikarenakan mengalami kendala koneksi internet yang lambat dan kurang stabil. Kendala ini dapat dimaklumi karena dalam waktu bersamaan guru harus menggunakan aplikasi Zoom dan membuka situs Edpuzzle, sehingga bandwith data yang diperlukan sangat besar. Guru-guru yang dapat bergabung dalam kelas simulasi kemudian mencoba fitur-fitur yang terdapat di dalam Edpuzzle, seperti video yang tidak dapat dilewati (skip), video akan berhenti jika berpindah jendela atau tab, pertanyaan yang muncul di tengah video dan lain-lain. Di akhir sesi simulasi, dosen pemateri menunjukkan statistik pengerjaan soal yang telah dilakukan guru. Beberapa guru juga menyampaikan pendapat mereka tentang baiknya fitur-fitur ini untuk dimanfaatkan dalam pembelajaran di kelas. 


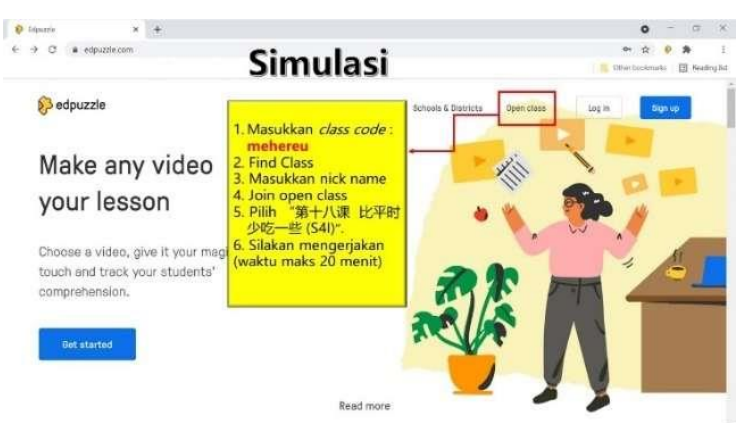

Gambar 3. Tahapan bergabung ke kelas simulasi Edpuzzle

Sesi selanjutnya dosen narasumber berbagi layar (share screen) untuk menjelaskan tahapan perancangan video dengan Edpuzzle mulai dari mendaftar akun, menyambungkan video dari Youtube ke Edpuzzle, menambahkan soal-soal dalam video, membuat kelas untuk siswa hingga cara membagikan tautan video hasil rancangan kepada siswa. Para guru mengikuti dengan seksama dan langsung melakukan praktik perancangan video. Beberapa guru juga mengajukan pertanyaan jika ada tahapan yang tertinggal atau tidak sama seperti yang dijelaskan dosen narasumber.

Setelah sesi praktik pembuatan video selesai, dipilih dua orang guru peserta untuk mempresentasikan hasil video rancangannya. Dari presentasi tersebut terlihat guru-guru peserta telah memahami bagaimana cara membuat dan menggunakan fitur-fitur yang ada di Edpuzzle, sehingga dapat dikatakan pelatihan pembuatan materi di Edpuzzle ini berhasil.

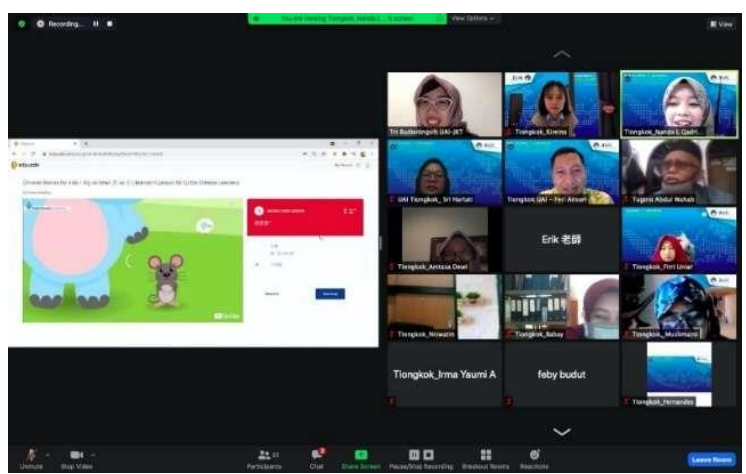

Gambar 4. Presentasi video rancangan peserta

Di bagian akhir kegiatan abdimas ini, terdapat sesi tanya jawab dan sharing pengalaman guru-guru dalam pembelajaran daring yang telah dilakukan di kelas. Guru-guru peserta terlihat sangat antusias dan terlibat aktif dalam sesi ini. Seorang guru peserta juga membagikan pengalamannya merancang dan menggunakan media video dalam pembelajaran dan memperkenalkan kanal Youtube yang khusus dibuatnya untuk mengunggah video pembelajaran. Video pembelajaran yang dibuat dapat menjadi referensi bagi guru-guru peserta untuk digunakan di kelas yang diampu. Kegiatan ditutup dengan sesi foto bersama dan pembagian kuesioner.

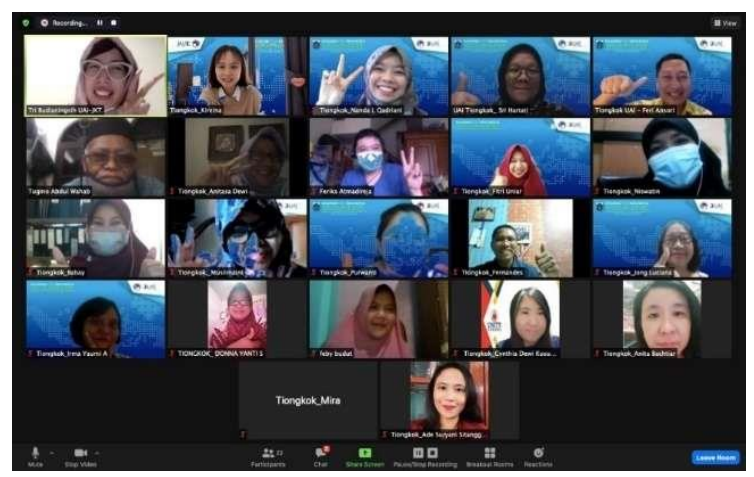

Gambar 5. Foto bersama panitia dan peserta kegiatan pelatihan

Data kuesioner menunjukkan $94,4 \%$ peserta pelatihan yang terdiri dari guru-guru bahasa Mandarin tingkat SMA/sederajat ini pernah menggunakan media video dalam pembelajaran bahasa Mandarin. Sebanyak 61,1\% guru pernah membuat video pembelajaran sendiri. Mereka mengunggah dan membagikan video yang telah dibuat ke dalam platform Youtube (40\%), Google Drive $(26.7 \%)$ dan grup Whatsapp kelas (26.7\%). Bahkan 50\% dari guru-guru yang mengikuti pelatihan memiliki kanal Youtube pribadi yang dimanfaatkan untuk mengunggah video pembelajaran yang telah dibuat. Hal ini menunjukkan dalam pembelajaran bahasa Mandarin, penggunaan video pembelajaran sudah bukan menjadi hal yang baru dan asing bagi guru-guru.

Pelatihan ini bertujuan agar penggunaan media video dalam pembelajaran dapat berlangsung lebih efektif, terkontrol dan mendapatkan hasil yang maksimal. Selain itu untuk menjawab kebutuhan guru akan informasi aplikasi penunjang pembelajaran yang bersifat seperti kuis atau game untuk diterapkan di kelas daring. Kegiatan pembelajaran daring yang sudah berlangsung selama lebih dari satu tahun membuat para peserta didik mulai kehilangan motivasi untuk belajar, terutama bagi siswa-siswi sekolah yang lebih mudah jenuh dalam belajar. Oleh karena itu diperlukan inovasi dari guru untuk mengembangkan model dan metode 
pembelajaran untuk meningkatkan minat belajar siswa.

Penggunaan Edpuzzle dalam pembelajaran terbukti efektif, menarik dan menyenangkan, hal ini telah dibuktikan dalam pembelajaran mata kuliah Kemahiran Bahasa Mandarin Lisan dan Tertulis di tingkat I, II dan III Prodi Bahasa Mandarin dan Kebudayaan Tiongkok Universitas Al Azhar Indonesia. Beberapa penelitian tentang pemanfaatan Edpuzzle dalam pembelajaran di tingkat sekolah juga menunjukkan hasil serupa. Sirri (2020) dalam penelitiannya terhadap siswa MTs Al Ishlah Cihaurbeuti menyatakan siswa merasa pembelajaran dengan media Edpuzzle selain menyenangkan, juga dapat meningkatkan kemandirian belajar dan membantu mereka memahami konsep materi yang diajarkan. Siswa juga merasakan kemajuan belajar yang dibuktikan dengan hasil tes yang memuaskan. Kegiatan KKN dengan menerapkan pembelajaran Edpuzzle pada siswa tingkat sekolah dasar di Jalan Panjang Kampung Baru juga menunjukkan respon yang positif dari siswa. Siswa merasa puas, senang dan memperoleh manfaat dalam mengikuti kegiatan pembelajaran dengan Edpuzzle (Sundi, 2021).

Hal ini juga dirasakan oleh guru-guru yang mengikuti simulasi dan perancangan video Edpuzzle pada pelatihan ini. Hasil kuesioner menunjukkan tingkat kepuasan guru-guru terhadap kegiatan pelatihan ini mencapai $92,2 \%$, guru-guru merasa pelatihan ini sangat bermanfaat untuk menambah referensi metode pengajaran mereka dan akan menerapkannya di kelas.

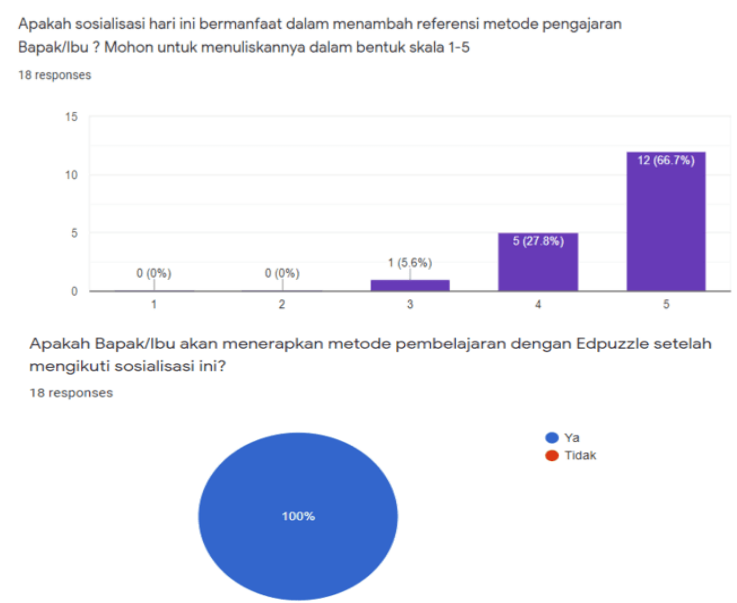

Gambar 6. Hasil kuesioner peserta pelatihan

\section{SIMPULAN DAN SARAN}

Youtube dan Edpuzzle merupakan platform berbagi video yang dapat dikombinasikan dan dimanfaatkan sebagai penunjang pembelajaran di kelas. Dalam pembelajaran daring, metode pembelajaran dengan video dapat menjadi salah satu alternatif untuk menciptakan suasana belajar yang menyenangkan, efektif dan interaktif. Pelatihan pemanfaatan Youtube dan Edpuzzle ini dapat dikatakan berhasil karena berdasarkan data kuesioner, tingkat kepuasan peserta yang terdiri dari guru-guru tingkat SMA/sederajat mencapai 92,2\%. Mereka mendapatkan manfaat dari pelatihan ini dan akan menerapkan pengetahuan yang didapat ke dalam pembelajaran di kelas.

Pelatihan ini juga menjawab kebutuhan guru-guru SMA/Sederajat akan informasi mengenai metode, media maupun platform yang interaktif yang dapat digunakan dalam pembelajaran. Seluruh rangkaian kegiatan pengabdian masyarakat ini kami unggah di kanal Youtube Prodi kami dengan judul "Pengabdian kepada Masyarakat - S4I : Sosialisasi Metode Pembelajaran dengan Youtube dan Edpuzzle" agar bermanfaat bagi lebih banyak guru-guru yang membutuhkan informasi ini. (Tautan : https://youtu.be/3eDjUvdgFOY).

\section{UCAPAN TERIMA KASIH}

Terima kasih kepada Lembaga Penelitian dan Pengabdian Masyarakat Universitas Al Azhar Indonesia (LPPM UAI) yang telah memfasilitasi dan memberikan bantuan dana sehingga kegiatan pengabdian kepada masyarakat ini dapat berlangsung dengan baik dan lancar. Terima kasih juga atas antusias yang luar biasa dari guru-guru peserta kegiatan yang berasal dari Sekolah Menengah Atas Wilayah Suku Dinas I dan II Jakarta Pusat serta guru-guru yang tergabung dalam Musyawarah Guru Mata Pelajaran (MGMP) wilayah Jabodetabek selama mengikuti kegiatan sosialisasi dan pelatihan ini.

\section{DAFTAR PUSTAKA}

Iskandarwassid. Suhendar, Dadang. (2013). Strategi Pembelajaran Bahasa (p.9), Bandung: Remaja Rosdakarya. 
Oktaviani, R. T. (2020). Pemanfaatan Video sebagai Media Pembelajaran dalam Pendidikan dan Pelatihan (Diklat). MADIKA: Media Informasi dan Komunikasi Diklat Kepustakawanan, 5(1), 91-94.

裴洋. (2013). 远程网络技术在对外汉语教学 中的应用研究. 吉林大学, 长春.

Sanjaya, Wina. (2010). Perencanaan dan Desain Sistem Pembelajaran (p.186). Jakarta: Kencana Prenada Media Group.

Sirri, E. L., \& Lestari, P. (2020). Implementasi Edpuzzle Berbantuan WhatsApp Group Sebagai Alternatif Pembelajaran Daring Pada Era Pandemi. JPMI (Jurnal Pendidikan Matematika Indonesia), 5(2), 67-72.
苏娟. (2020). 海外远程汉字教学模式分析. 现代交际. vol 21.p 174-176.

Sundi, V. H., Astari, T., Rosiyanti, H., \& Ramadhani, A. (2021, February). Efektivitas Penggunaan Edpuzzle dalam Meningkatkan Motivasi Belajar pada Masa Pandemi Covid-19. In Prosiding Seminar Nasional Pengabdian Masyarakat LPPM UMJ (Vol. 1, No. 1).

Website Edpuzzle: edpuzzle.com

Website Youtube: youtube.com

Yohanes Enggar Harususilo. Webinar Gratis Guru: Belajar Online Menyenangkan dengan EdPuzzle diakses dari Kompas.com (https://edukasi.kompas.com/read/2020/05/0 1/103352971/webinar-gratis-guru-belajaronline-menyenangkan-denganedpuzzle?page $=$ all). 